\title{
Spectrophotometric Method in Comparative In Vitro Dissolution Test of Branded and Generic Ibuprofen Tablets
}

\author{
Ana Marković1, Miroslava Spasić1, Vesna Savić1, Slavica Sunarić2 , Marija Tasić Kostov \\ ${ }^{1}$ University of Niš, Faculty of Medicine, Department of Pharmacy, Niš, Serbia \\ ${ }^{2}$ University of Niš, Faculty of Medicine, Department of Chemistry, Niš, Serbia
}

SUMMARY

The dissolution test is a simple and important in vitro method for assessing the bioequivalence, which aims to compare the bioavailability of generic and branded drugs. It implies the use of a proper apparatus (usually pharmacopoeially defined) in which the dosage form is dissolved, and the dissolution process itself is monitored/quantified using an appropriate analytical method among which highperformance liquid chromatography (HPLC) is widely used. Spectrophotometry could be a significant substitute, through its advantages in terms of simplicity and costs of analysis. In the present study, possible differences in bioavailability between branded and generic ibuprofen coated tablets were predicted using a dissolution test for solid dosage forms. The ibuprofen content and the amount of ibuprofen released in the dissolution test were determined using a simple spectrophotometric method. Based on the obtained results, no significant differences in the dissolution rate of ibuprofen from generic and branded coated tablets were observed. It can be concluded that the spectrophotometric method applied for the dissolution test, among other suitable methods, could be used for bioequivalence screening in conditions where rapid and simple assessment is required or where HPLC method is not available.

Key words: dissolution test, ibuprofen, bioequivalence, generic drug, branded drug

Corresponding author:

Ana Marković

e-mail: anule89@yahoo.com 


\section{INTRODUCTION}

A drug is a product that is marketed in specific strength, pharmaceutical form, and packaging, containing a compound or combination of compounds that have been shown to treat or prevent diseases in humans or animals, as well as a compound or combination of compounds that may be used or administered to humans or animals, with the intention of restoring, improving or altering physiological function through pharmacological, immunological or metabolic action or making a medical diagnosis (1). Except for intravenous drug administration, for all other administration routes, it is necessary that the active compound is first absorbed in order to exhibit its pharmacological activity. Before being absorbed, a compound given in a particular pharmaceutical form must first be released from a dosage form and dissolved at the application site. The release and absorption of the active compound are controlled by the characteristics of the active compound and the drug form, as well as by the medium at the administration or resorption site (2 4). The degree and rate at which an active compound of a given dosage form reaches the systemic circulation is bioavailability (4). The oral route is the most common route of drug administration. Oral dosage forms are absorbed in the digestive tract, mainly in the small intestine, primarily in the duodenum due to a suitable $\mathrm{pH}$, rich vascularization, and large surface area (2).

In recent years, the use of generic drugs has been steadily increasing, since they are $20-90 \%$ cheaper than branded drugs (5). The branded drug contains a new active compound or a new combination of already existing active compounds, has a trading name, and is protected by a patent, so it can only be manufactured and sold by the pharmaceutical company that first discovered it. After patent expiration, other pharmaceutical companies can start manufacturing a so-called generic drug, modeled after a given branded drug (6). A generic drug has the same qualitative and quantitative composition of the active compounds and the same pharmaceutical form as the branded drug, and its bioequivalence to the branded drug has been demonstrated by appropriate bioavailability studies (1).

The approval of the branded drug in the Republic of Serbia or the European Union is granted based on complete documentation on the drug quality, safety, and efficacy following the relevant re- quirements (1). The efficacy and safety of the branded drug are determined by controlled preclinical and clinical studies. However, a generic drug does not go through these tests but relies on data collected for a branded drug. A key stage in generic drug development is the bioequivalence study $(5,7)$. Bioequivalence is defined as the absence of a significant difference in the rate and degree in which an active compound from pharmaceutical equivalents or alternatives reaches the site of action when equivalents or alternatives are administered at the same dose and under the same conditions in a properly designed study (8). Bioequivalence variations are allowed in the range of 80 to $125 \%$, and 90 to $111 \%$ for drugs with narrow therapeutic widths (9). Therefore, bioequivalence studies aim to compare the bioavailability of generic and branded drugs. Several in vivo (pharmacokinetic, pharmacodynamic and clinical studies) and in vitro methods can be used for bioequivalence determination. For per os drugs containing highly soluble and highly permeable compounds, in vitro dissolution test can provide not only product quality control but also predict in vivo drug behavior. This bioequivalence testing approach is made possible by the development of a biopharmaceutical classification system (BCS) of drugs (8).

Besides knowing the solubility and the dissolution rate of the active compound itself, from a biopharmaceutical point of view, it is also important to know the dissolution rate of the active compound from the pharmaceutical form (4). Dissolution test for solid dosage forms (tablets, capsules, suppositories) is a standard official method prescribed in European Pharmacopoeia 9.0 (10) and in the Yugoslav Pharmacopoeia 2000 as well (11). It implies the use of the proper analytical method; high-performance liquid chromatography (HPLC) as a highly sensitive and specific method is widely used. However, spectrophotometry may come into consideration due to its rapidity, simplicity, accuracy, and inexpensive instrumentation, and hence it could be a significant substitute to more demanding analytical methods such as HPLC. One of the important disadvantages of UV spectrophotometric methods is poor selectivity and specificity. Therefore, it is necessary to examine whether the application of the direct UV spectrophotometric method for the determination of ibuprofen in dissolution tests exhibits good selectivity regardless of the difference in the excipients present in the generic and branded drugs. 
Ibuprofen (2-(4-(2-methylpropyl)phenyl) propanoic acid), a propionic acid derivative, belongs to the group of nonsteroidal anti-inflammatory drugs (NSAIDs), and they are often sold over-thecounter (OTC). Its main mechanism of action is the non-selective, reversible inhibition of the cyclooxygenase enzyme COX-1 and COX-2 (12). Ibuprofen is usually given orally. It is rapidly and completely absorbed from the gastrointestinal tract (13). Due to its analgesic, anti-inflammatory, and antipyretic properties, ibuprofen is used to treat mild to moderate pain, inflammation, and fever (14). Ibuprofen was selected for this study because of its wide range of biological activities, good tolerability profile, efficacy, safety, and availability. It is rated as one of the safest conventional NSAIDs and is also on the WHO list of essential medicines. Since ibuprofen belongs to BCS class II (drugs with low solubility and high permeability), and in this case the absorption rate is limited by drug dissolution, biorelevant dissolution tests can predict the difference in bioavailability, i.e. a strong correlation between in vitro dissolution and in vivo absorption can be established $(15,16)$.

In this study, we investigated potential differ- ences in dissolution rate between branded and generic ibuprofen coated tablets registered in Serbia. The investigated ibuprofen tablets were also tested for mass variation and active compound content.

\section{MATERIAL AND METHODS}

\section{Apparatus and reagents}

The standard substance of ibuprofen (ibuprofen sodium, analytical standard, $\geq 98 \%$ ) was obtained from Sigma-Aldrich Chemie GmbH (Germany). The spectrophotometric analyses were performed on an Evolution 60 spectrophotometer (Thermo-Fisher Scientific USA). The dissolution test was performed using Dissolution Tester DT 126 light (ERWEKA GmbH, Germany).

\section{Studied pharmaceutical forms}

Samples of commercially available ibuprofen tablets which characteristics (17) are presented in Table 1 were analyzed as part of the experimental work. All tablets were stored under the same conditions for the duration of the test.

Table 1. Characteristics of the tested ibuprofen tablets (17)

\begin{tabular}{|c|c|c|}
\hline & Branded drug & Generic drug \\
\hline Name & Brufen $^{\circledR}$ & Ibuprofen \\
\hline INN & Ibuprofen & Ibuprofen \\
\hline Manufacturer & $\begin{array}{c}\text { Famar A.V.E. Anthoussa } \\
\text { Plant } \\
\end{array}$ & Union-Medic D.O.O. Novi Sad \\
\hline Pharmaceutical form & Coated tablet & Coated tablet \\
\hline Declared content & $400 \mathrm{mg}$ & $400 \mathrm{mg}$ \\
\hline Description & $\begin{array}{c}\text { White, oval, biconvex } \\
\text { coated tablet }\end{array}$ & $\begin{array}{l}\text { Oblong, biconvex red-pink coated tablets, with } \\
\text { imprinted sub-line on both sides, white at the break }\end{array}$ \\
\hline Excipients (core) & $\begin{array}{l}\text { Cellulose, microcrystalline } \\
\text { Croscarmellose sodium } \\
\text { Lactose monohydrate } \\
\text { Silica, colloidal anhydrous } \\
\text { Sodium lauryl sulfate } \\
\text { Magnesium stearate } \\
\end{array}$ & $\begin{array}{l}\text { Silica, colloidal anhydrous } \\
\text { Povidone (K25) } \\
\text { Croscarmellose sodium } \\
\text { Starch, corn } \\
\text { Cellulose, microcrystalline }\end{array}$ \\
\hline $\begin{array}{l}\text { Excipients } \\
\text { (coating-layer) }\end{array}$ & $\begin{array}{c}\text { Hypromellose } \\
\text { Titanium dioxide } \\
\text { Talc }\end{array}$ & $\begin{array}{c}\text { Hypromellose } \\
\text { Talc } \\
\text { Titanium dioxide (E171) } \\
\text { Macrogol } 8000 \\
\text { Erythrosine (E127) }\end{array}$ \\
\hline
\end{tabular}


Mass variation of the studied ibuprofen tablets

Twenty randomly selected tablets were individually weighed and the average mass was calculated. Not more than two of the individual masses shall deviate from the average mass by more than the allowed percentage deviation and none shall deviate by more than twice that percentage $(10,11)$.

\section{Determination of ibuprofen content}

\section{Construction of a calibration curve}

The standard substance of ibuprofen was weighed in the amount of $25 \mathrm{mg}$, then transferred to a $50 \mathrm{ml}$ volumetric flask and dissolved in $0.1 \mathrm{M}$ $\mathrm{NaOH}$. It was shaken until the substance was completely dissolved and then filled up to the mark of the volumetric flask. Quantities of 2, 4, 6, 8, and 10 $\mathrm{ml}$ of the prepared solution were pipetted, transferred individually into $10 \mathrm{ml}$ volumetric flasks, and filled up to the mark with $0.1 \mathrm{M} \mathrm{NaOH}$ solution. By measuring the absorbance of the prepared standard solutions at $264 \mathrm{~nm}(10,11)$, using distilled water as a blank, a calibration curve $A=f(c)$ was constructed.

Test samples preparation

Three of each branded and generic tablets were used to determine the content of ibuprofen. For both the branded and the generic drug, the mass of each of the three tablets was measured and the average tablet mass was calculated. After removing the coated-layer mechanically, each of the tested tablets was pulverized in a laboratory mortar with a pestle, and then the mass that, according to the manufacturer's declaration, contains $25 \mathrm{mg}$ of ibuprofen was weighed. The measured mass was transferred to a 50 $\mathrm{ml}$ volumetric flask, $25 \mathrm{ml}$ of $0.1 \mathrm{M} \mathrm{NaOH}$ solution was added, shaken for several minutes, and then filled up to the mark with $\mathrm{NaOH}$ solution. Each of the prepared solutions was filtered through filter paper. Thereafter, $4 \mathrm{ml}$ of the solution was pipetted into a $10 \mathrm{ml}$ volumetric flask and filled up with $\mathrm{NaOH}$ solution. The absorbances of the test samples were measured at $264 \mathrm{~nm}$, using distilled water as a blank, and then, based on the calibration equation, the concentration of ibuprofen in the test samples was determined. The content of ibuprofen in tablets should be 95 - 105\% of the declared content (18).

\section{Dissolution test of the studied ibuprofen} tablets

To test the dissolution rate of ibuprofen from the studied coated tablets, paddle apparatus was used, adjusting the following experimental conditions: rotation speed to $50 \mathrm{rpm}$, dissolution medium temperature to $37^{\circ} \mathrm{C}$, and the total test duration to 30 minutes. Phosphate buffer (0.5 M, pH 7.2) in a volume of $900 \mathrm{ml}$ was used as the dissolution medium. The apparatus was positioned so that there were no significant movements or vibrations in it or in its surroundings, except for the uniform rotation of the moving elements or the operation of the flow system. At intervals of 5, 10, 15, 20, 25 and 30 minutes, $10 \mathrm{ml}$ of each sample was taken using a syringe (11, 19, 20). Sampling was carried out from a position halfway between the surface of the dissolution medium and the bottom of the paddle, and at least 10 $\mathrm{mm}$ away from the vessel wall (11). The volume reduction due to sampling was subsequently calculated. The test samples were filtered through filter paper and then their absorbances were measured at $264 \mathrm{~nm}$. Using the previously obtained calibration equation, the percentage of ibuprofen released from the tested coated tablets at the studied time intervals was calculated $(11,19,20)$.

\section{RESULTS}

Mass variation of the studied ibuprofen tablets

Table 2. Individual and average masses of the studied ibuprofen tablets

\begin{tabular}{|c|c|c|c|c|}
\hline & \multicolumn{2}{|c|}{$\begin{array}{c}\text { Branded drug } \\
\left(\text { Brufen }^{\circledR}\right)\end{array}$} & \multicolumn{2}{|c|}{$\begin{array}{l}\text { Generic drug } \\
\text { (Ibuprofen) }\end{array}$} \\
\hline \multirow{10}{*}{$\begin{array}{l}\text { Individual } \\
\text { tablet mass } \\
\quad(\mathrm{mg})\end{array}$} & 521.7 & 522.0 & 652.3 & 659.5 \\
\hline & 526.9 & 526.1 & 654.8 & 656.4 \\
\hline & 525.6 & 521.1 & 659.7 & 652.3 \\
\hline & 533.4 & 526.3 & 657.1 & 650.6 \\
\hline & 526.9 & 521.8 & 657.1 & 656.4 \\
\hline & 521.7 & 526.0 & 656.9 & 659.7 \\
\hline & 521.8 & 522.0 & 653.3 & 655.1 \\
\hline & 526.3 & 525.6 & 659.5 & 654.8 \\
\hline & 526.0 & 533.4 & 656.9 & 650.6 \\
\hline & 521.1 & 526.1 & 655.1 & 653.3 \\
\hline $\begin{array}{c}\text { Average } \\
\text { tablet mass } \\
(\mathrm{mg}) \pm \mathrm{SD}\end{array}$ & \multicolumn{2}{|c|}{$525.1 \pm 3.6$} & \multicolumn{2}{|c|}{$655.6 \pm 2.9$} \\
\hline
\end{tabular}

SD - Standard deviation 
Table 2 shows the mass values of each measured ibuprofen tablet, as well as their average mass. Since the tablet mass of both branded and generic drugs was greater than $250 \mathrm{mg}$, the percentage deviation should not exceed $5 \%(10,11)$. Therefore, the upper and the lower deviation limits for the branded drug were $551.4 \mathrm{mg}$ and $498.8 \mathrm{mg}$, respectively, while the upper and the lower deviation limits for the generic drug were $688.4 \mathrm{mg}$ and 622.8 $\mathrm{mg}$, respectively.

\section{Determination of ibuprofen content}

Based on the results obtained by measuring the absorbance of the prepared solutions of the tested ibuprofen tablets (declared concentration of $0.2 \mathrm{mg} / \mathrm{ml}$ ) and the previously constructed calibration curve (Figure 1), the content of ibuprofen in the studied coated tablets was calculated (Table 3).

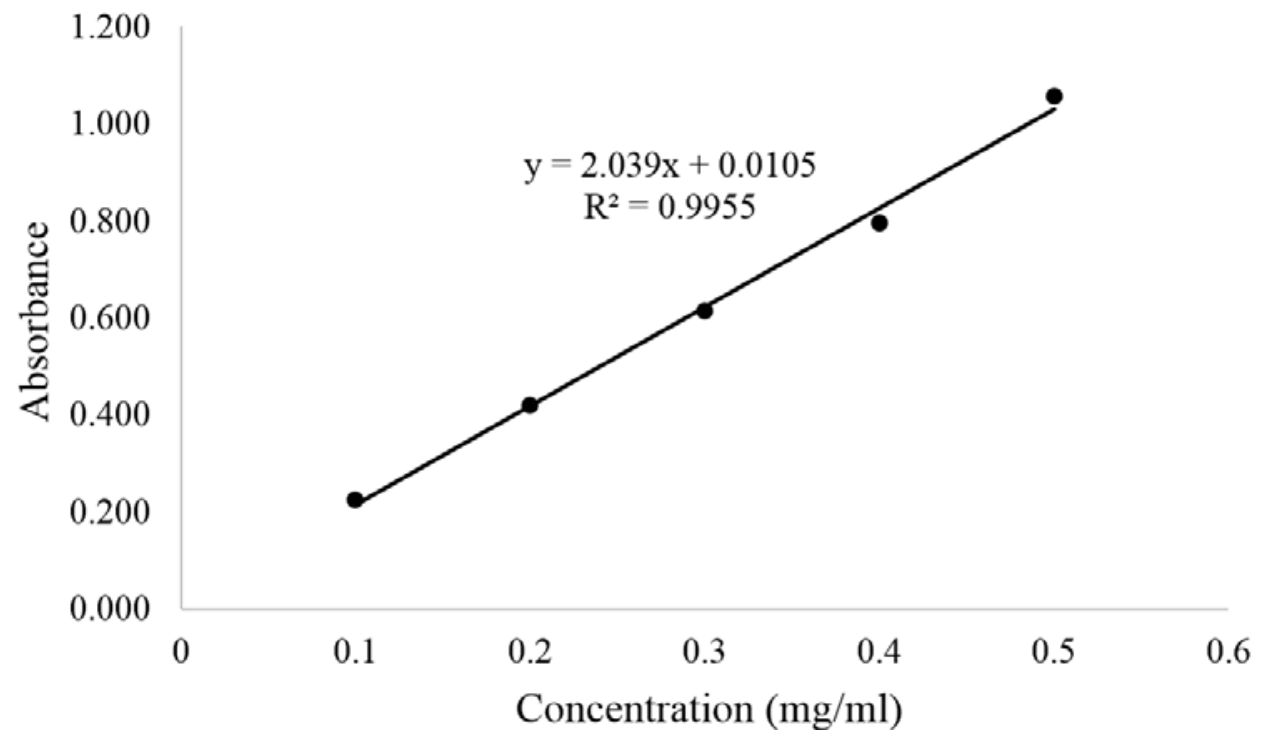

Figure 1. Calibration curve of ibuprofen

Table 3. Ibuprofen content in the studied tablets determined by the calibration method

\begin{tabular}{|c|c|c|c|c|c|}
\hline Tablet & Sample & Absorbance & $\begin{array}{c}\text { Found } \\
\text { concentration } \\
(\mathrm{mg} / \mathrm{ml}) \\
\end{array}$ & $\begin{array}{c}\text { Declared } \\
\text { concentration } \\
(\mathrm{mg} / \mathrm{ml}) \\
\end{array}$ & $\begin{array}{l}\text { Percentage } \\
\text { of declared } \\
\text { content (\%) } \\
\end{array}$ \\
\hline \multirow{4}{*}{ Brufen $^{\circledR}$} & 1 & 0.424 & 0.203 & 0.200 & 101.40 \\
\hline & 2 & 0.438 & 0.210 & 0.200 & 104.83 \\
\hline & 3 & 0.424 & 0.203 & 0.200 & 101.40 \\
\hline & $\bar{x} \pm$ SD & $0.429 \pm 0.008$ & $0.205 \pm 0.004$ & $0.200 \pm 0.000$ & $102.54 \pm 1.98$ \\
\hline \multirow{4}{*}{ Ibuprofen } & 1 & 0.439 & 0.210 & 0.200 & 105.08 \\
\hline & 2 & 0.440 & 0.211 & 0.200 & 105.32 \\
\hline & 3 & 0.435 & 0.208 & 0.200 & 104.10 \\
\hline & $\bar{x} \pm$ SD & $0.438 \pm 0.003$ & $0.210 \pm 0.002$ & $0.200 \pm 0.000$ & $104.83 \pm 0.65$ \\
\hline
\end{tabular}


Dissolution test of the studied ibuprofen tablets

By spectrophotometric measurement of absorbances and using the previously obtained calibration equation, the concentration of ibuprofen, i.e. the percentage of dissolved ibuprofen in each of the tested samples (taken at appropriate time intervals) was determined. Based on the obtained results, dissolution profiles of the studied coated tablets of ibuprofen were constructed (Figure 2).

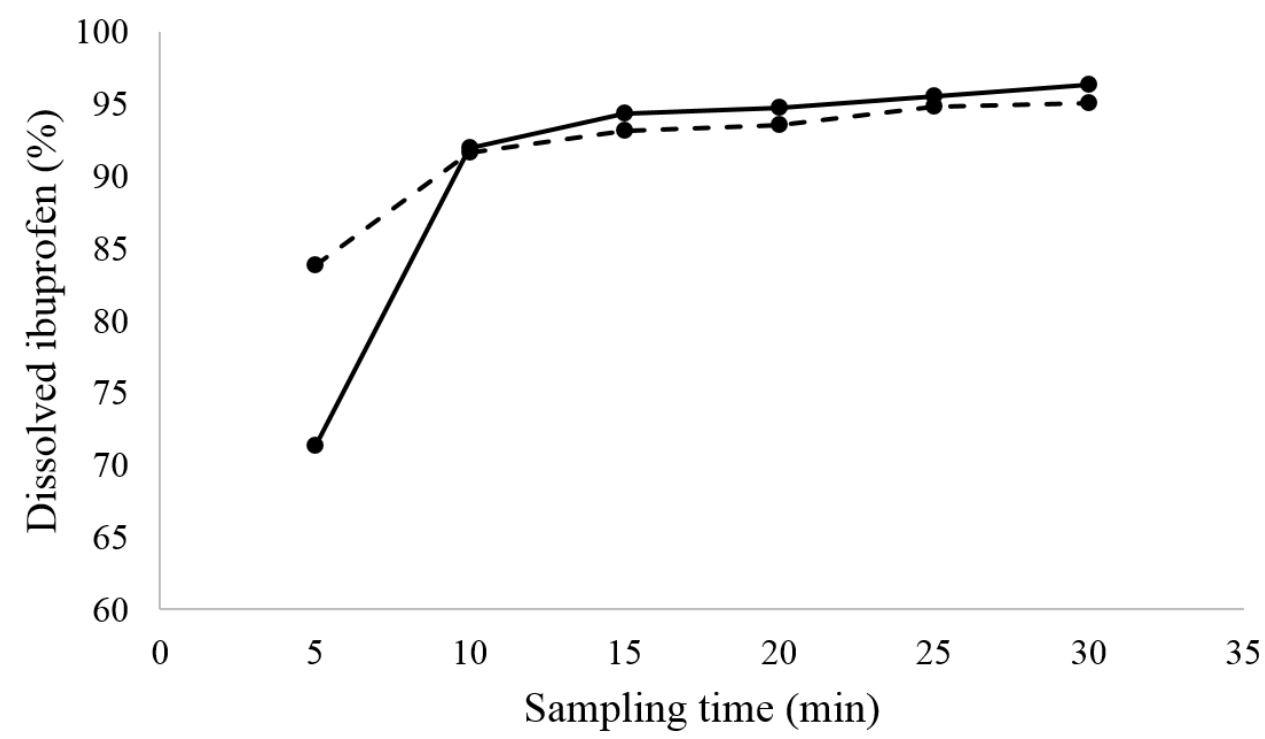

Figure 2. Dissolution profiles of branded (Brufen ${ }^{\circledR}$, full line) and generic (Ibuprofen, dashed line) drug

\section{DISCUSSION}

In the present study, the content of ibuprofen in the coated tablets, as well as the amount of ibuprofen released in the tablet dissolution test, were determined spectrophotometrically. Because of the specific and strong absorption band in the UV region, spectrophotometric methods have been widely used for the determination of NSAIDs, including ibuprofen.

\section{Mass variation of the studied ibuprofen} tablets

Based on the obtained results, it was shown that both branded (Brufen ${ }^{\circledR}$ ) and generic (Ibuprofen) drugs were produced by $\mathrm{Ph}$. Eur. 9.0, that is, no masses exceeded the permitted 5\% (Table 2).

\section{Determination of ibuprofen content}

It can be seen that there were no significant differences in the content of ibuprofen between the branded and generic drugs; also, the ibuprofen content in the studied coated tablets (Brufen ${ }^{\circledR}$ and Ibuprofen) was within the tolerance range (95 $105 \%$ ) (Table 3). Based on the agreement of the found and declared ibuprofen content, it can be concluded that the applied spectrophotometric method shows good selectivity and accuracy for both tablet products. Relative standard deviations were $1.93 \%$ and $0.62 \%$ which indicates good precision of the method.

\section{Dissolution test of the studied ibuprofen} tablets

It can be observed that after the first sampling (after $5 \mathrm{~min}$ ), the percentage of dissolved ibuprofen from the generic drug (Ibuprofen) was slightly higher than the percentage of dissolved ibuprofen from the branded drug (Brufen ${ }^{\circledR}$ ) (Figure 2). However, by examining the samples taken at other time intervals, no significant difference in the dissolution rate of ibuprofen was observed between the branded (Brufen ${ }^{\circledR}$ ) and generic (Ibuprofen) drug. Finally, after 30 minutes of testing, the percentage of dissolved ibuprofen in both cases was over 95\% (Figure 2). 
According to the above results obtained using spectrophotometry as the analytical method, which indicates a satisfactory and mutually similar dissolution profile of the studied ibuprofen tablets, it was confirmed that both generic and branded drugs have similar bioavailabilities. So, the in vitro dissolution test employing spectrophotometric analysis described in this paper can be proposed as a fast, simple, accurate, and widely available technique for bioequivalence studies, when it is possible.

The limiting factor in complex pharmaceutical product analysis may be interferences by certain excipients. Coating agents or artificial colors and sweeteners often used in solid pharmaceutical products can cause significant interferences and inaccurate analysis results. Therefore, it is necessary to validate the spectrophotometric method in terms of selectivity before it is applied to the dissolution test. Also, since counterfeit drugs often differ from the original drugs in the excipients they contain, this simple method can give significantly different results in case that excipients show spectrophotometric interference with an active substance.

\section{CONCLUSION}

Ibuprofen is the most commonly used and most frequently prescribed NSAID. In the present study, the dissolution rate of ibuprofen from coated tablets of the branded $\left(\right.$ Brufen $\left.^{\circledR}\right)$ and generic (Ibuprofen) manufacturer, registered in Serbia, was examined and compared. The obtained results indicate that there was no significant difference in the dissolution rate of ibuprofen between branded and generic coated tablets. Also, the studied coated tablets showed no significant difference in mass variation and ibuprofen content. Based on the aforementioned, it can be concluded that both branded and generic ibuprofen coated tablets, which are one of the most commonly used dosage forms of ibuprofen among patients in Serbia, were produced under current regulations, and that relatively similar bioavailability of the branded (Brufen ${ }^{\circledR}$ ) and generic (Ibuprofen) drug can be expected in vivo.

The in vitro dissolution test employing spectrophotometry described in this paper can therefore be used for bioequivalence screening, determination of branded and generic drugs substitutability or detection of substandard and counterfeit drugs containing NSAIDs, particularly ibuprofen. The method could be useful when a rapid assessment is required and when more expensive and more demanding analytical techniques, or in vivo methods are not available.

\section{References}

1. Zakon o lekovima i medicinskim sredstvima ("Sl. glasnik RS" br. 30/2010, 107/2012, 105/17-dr.zakon i 113/2017-dr.zakon)

2. Swarbrick J, Boylan JC. Encyclopedia of pharmaceutical technology, second edition. Marcel Dekker, 2002; 156-75.

3. Pokrajac M. Farmakokinetika. Beograd, Grafolik; 2002.p. 21-46.
4. Parojčić J, Ibrić S, Đurić Z. Farmaceutska tehnologija sa biofarmacijom, priručnik za praktičnu nastavu. Beograd; 2006. p 7-10.

5. Dunne S, Shannon B, Dunne C, et al. A review of the differences and similarities between generic drugs and their originator counterparts, including economic benefits associated with usage of generic medicines, using Ireland as a case study. BMC Pharmacol Toxicol 2013; 14(1):1. 
https://doi.org/10.1186/2050-6511-14-1

6. Swarbrick J. Encyclopedia of pharmaceutical technology, third edition. Informa Healthcare, New York London, 2007; 1891-6.

7. Jakovljević MB, Janković SM. Studije bioekvivalencije. Acta Med Median 2006; 45(4):50-5.

8. Guidance for industry: Bioavailability and bioequivalence studies for orally administered drug products - general considerations. U.S. Department of Health and Human Services, Food and Drug Administration, Center for Drug Evaluation and Research (CDER), July 2002. (Cited 2021 Jan 9).Available from:

https://www.fda.gov

9. Committee For Medicinal Products For Human Use: European Medicines Agency website, Guideline on the Investigation of Bioequivalence, European Medicines Agency, 2010. (Cited 2021 Jan 9).Available from:

https://www.ema.europa.eu

10. European Pharmacopoeia. Strasbourg: Council of Europe, 2016. . (Cited 2021 Jan 9).Available from: https://www.edqm.eu

11. Jugoslovenska farmakopeja 2000, peto izdanje. Savezni zavod za zaštitu i unapređenje zdravlja, Savremena administracija, Beograd, 2000.

12. Mazaleuskaya LL, Theken KN, Gong L, et al. PharmGKB summary: ibuprofen pathways. Pharmacogenet Genom 2015; 25(2):96-106.
https://doi.org/10.1097/FPC.0000000000000113

13. Davies NM. Clinical pharmacokinetics of ibuprofen. Clin Pharmacokinet 1998; 34(2):101-54. https://doi.org/10.2165/00003088-199834020-00002

14. Sweetman SC. Martindale: the complete drug reference $36^{\text {th }}$ ed. London; Chicago: Pharmaceutical Press, 2009; p.64-6.

15. Dressman JB, Reppas C. In vitro-in vivo correlations for lipophilic, poorly water-soluble drugs. Eur J Pharm Sci 2000; 11:S73-80. https://doi.org/10.1016/S0928-0987(00)00181-0

16. Dhingra G, Sreelesh B, Nagpal M, et al. In-vitro dissolution testing of ibuprofen using compendial and biorelevant dissolution media. Res J Pharm Technol 2010; 3(3):931-3.

17. Alims.gov.rs. Agencija za lekove i medicinska sredstva Srbije (Cited 2021 Jan 9). Available from: http://www.alims.gov.rs/

18. Pharmacopoea Jugoslavica. Editio quarta (Ph. Jug. IV). Savezni zavod za zdravstvenu zaštitu, Beograd, 1984: 496-7.

19. Bosanquet AG, Betteridge RF. Comparison of dissolution rates of ibuprofen tablets. Int J Pharm Pract 1993; 2(2):114-6. https://doi.org/10.1111/j.2042-7174.1993.tb00738.x

20. Romero AJ, Grady LT, Rhodes CT. Dissolution testing of ibuprofen tablets. Drug Dev Ind Pharm 1988; 14(11):1549-86.

https://doi.org/10.3109/03639048809151949 


\title{
Primena spektrofotometrije $\mathbf{u}$ in vitro studiji poređenja brzine oslobađanja aktivne supstance iz brendiranih i generičkih tableta ibuprofena
}

\author{
Ana Marković1, Miroslava Spasić1, Vesna Savić1, Slavica Sunarić2, Marija Tasić Kostov¹ \\ ${ }^{1}$ Univerzitet u Nišu, Medicinski fakultet, Departman za farmaciju, Niš, Srbija \\ ${ }^{2}$ Univerzitet u Nišu, Medicinski fakultet, Departman za hemiju, Niš, Srbija
}

\section{SAŽETAK}

Ispitivanje brzine rastvaranja lekovite supstance iz lekovitog oblika (dissolution test) jednostavna je i značajna in vitro metoda za procenu bioekvivalencije, a koja za cilj ima upoređivanje bioraspoloživosti generičkog i brendiranog leka. Sama metoda podrazumeva primenu odgovarajuće aparature (najěešće farmakopejski definisane), u kojoj se lekoviti oblik rastvara, a primenom odgovarajuće analitičke metode prati/kvantifikuje sam proces rastvaranja, među kojima se tečna hromatografija visokih performansi (HPLC) široko koristi. Spektrofotometrija bi mogla biti značajna zamena, zahvaljujući svojim prednostima u pogledu jednostavnosti i ekonomičnosti. U ovom radu su, ispitivanjem brzine rastvaranja lekovite supstance iz čvrstog lekovitog preparata, predviđene eventualne razlike u bioraspoloživosti između brendiranih $i$ generičkih obloženih tableta ibuprofena. Sadržaj ibuprofena i količina ibuprofena oslobođenog pri ispitivanju brzine rastvaranja određeni su jednostavnom spektrofotometrijskom metodom. Rezultati ove studije pokazuju to da između ispitivanog generičkog i brendiranog leka ne postoje značajnije razlike $u$ brzini rastvaranja ibuprofena. Može se zaključiti to da bi se spektrofotometrijska metoda, koja se primenjuje za ispitivanje brzine rastvaranja lekovite supstance iz lekovitog oblika (dissolution test), uz druge, pogodne metode, mogla koristiti za skrining bioekvivalencije u uslovima koji zahtevaju brzu i jednostavnu procenu ili kada HPLC metoda nije dostupna.

Ključne reči: dissolution test, ibuprofen, bioekvivalencija, generički lek, brendirani lek 